\title{
(Ne)morální advokáti: problém ospravedlnění norem profesní etiky
}

\section{(Im)moral Lawyers: Problem of Justifying Norms of Professional Ethics}

\author{
Martin Hapla*
}

\begin{abstract}
Abstrakt
Normy profesni etiky často stanovi advokátuim pri výkonu jejich profese odlišné standardy chováni, nežjaké by v totožné situaci platily pro obyčejnébo člověka. Clánek se zabývá otázkou, jak müřeme tyto rozdíly ospravedlnit prostrednictvím rizných etických teorii. Autor v nèm nejprve charakterizuje profesni etiku advokáti jako soubor právnich a morálnich norem. Následnè analyzuje samotný problém její justifikace. Pozornost je vènována nejprve rionním deontologickým přstupuim (napr. Charles Fried, David Luban). Autor rozebirá jejich nedostatky a dospivá k závèru, že musi primárně zduirazñovat význam morálního a racionálního aktérství, pokud maji být vèrohodné. V strǐcnè se pak stavi k. utilitaristickému ospravedinèní. Také to je podle nèj v kombinaci s některými pragmatickými bledisky schopno profesni etiku advokátù věrohodně justiflkovat. Obě skupiny přstupư lze tedy považovat za relevantni a neni proto vhodné z debat o výse uvedené etice něketerý z nich vylučovat.
\end{abstract}

\section{Klíčová slova}

Etika právnických profesí; právni a morálni normy; normativni systém; justifikace; etické teorie; deontologická etika; utilitarismus.

\begin{abstract}
The norms of professional ethics often impose different standards of conduct on lawyers in the practicing of their profession than they would apply to an ordinary person in the same situation. The article analyzes how we can justify these differences through various ethical theories. The author describes the legal ethics as a set of legal and moral norms. He then analyzes the problem of its justification. Attention is first dedicated to various deontological approaches (eg Charles Fried, David Luban). The author analyzes their disadvantages and concludes that they must primarily emphasize the importance of moral and rational agency if they are to be credible. He evaluates utilitarian justification as appropriate. It is also this justification, combined with some pragmatic aspects, that is able to credibly justify the legal ethics. Both groups of approaches can be considered relevant and therefore it is not appropriate to exclude any of them from the professional ethics debate.
\end{abstract}

\section{Keywords}

Legal Ethics; Legal And Moral Norms; Normative System; Justification; Ethical Theories; Deontological Ethics; Utilitarianism.

\footnotetext{
* JUDr. Martin Hapla, Ph.D., Katedra právní teorie, Právnická fakulta, Masarykova univerzita, Brno / Department of Legal Theory, Faculty of Law, Masaryk University, Brno, Czech Republic / E-mail: Martin.Hapla@law.muni.cz
} 


\section{Úvod}

Každý, kdo se pohybuje v advokátní profesi, byl jistě alespoň jednou konfrontován s tím, že jeho povolání nevnímají někteři prríslušníci laické veřejnosti zrovna kladně. Často ve veřejném prostoru zaznívá kritika advokátů jako někoho, kdo se pohybuje na samé hranici toho, co je morální, pokud ne přímo hodně daleko za ní. Nejde zde přitom jen o to, že se v této profesi čas od času objeví někdo, kdo takř́kajíc porušuje pravidla hry, které jinak všichni obecně akceptují. Tím by se ostatně nějak zvlášt' nelišila od většiny ostatních zaměstnání. Pochybnosti, které zde vyvstávají, mají mnohem hlubší základ a lze je vyjádřit již klasickou otázkou Charlese Frieda, zda může být dobrý právník zároveň dobrý člověk. ${ }^{1}$ Není prrímo v genomu samotné advokátní profese zakódován i jistý gen zla? V praxi totiž vyvstávají situace, kdy normy profesní etiky advokátovi umožňují, aby se zachoval jinak, než by se většině lidí na první pohled jevilo jako správné. ${ }^{2}$ To pochopitelně vyvolává pochybnosti. Hlavním cílem tohoto článku je proto zodpovědět otázku, zda pro uvedené normy existuje rozumné ospravedlnění, jestli je onen rozpor mezi nimi a morálkou skutečným problémem, nebo jen zdánlivým. Bude zde tedy zkoumán teoretický problém právní vědy a etiky, nikoliv praktická otázka, kterou by bylo možno vyřešit rozborem právní úpravy nebo nějakého souboru kárných rozhodnutí. Zároveň je třeba již na tomto místě zdůraznit, že zde zkoumaný problém nemá jedno obecně přijatelné řešení. Naopak se tu nabízí větší množství různých cest, s nimiž jsou vždy spojeny určité výhody a nevýhody. Protože se navíc jedná o problematiku v našem prostředí zatím zcela neřešenou, bude smyslem tohoto článku především zmíněné cesty nastínit a rozebrat jejich silné a slabé stránky, nikoliv obhajovat, nebo kritizovat pouze jednu z nich.

S ohledem na vytčený cíl je tento text rozdělen do několika částí. První a nutný krok ke zkoumání otázky, jak lze normy profesní etiky advokátů ospravedlnit, spočívá v objasnění jejich povahy. Jedná se o normy právní, nebo morální? Je profesní etika ve skutečnosti vưbec etikou? Nedává v jejím případě větší smysl hovořit o právem stanovené

1 FRIED, Charles. The Lawyer as Friend: The Moral Foundations of the Lawyer-Client Relation. The Yale Law Journal, 1976, roč. 85, č. 8, s. 1060.

2 Za nejvíce ilustrativní považuji v této souvislosti případ Altona Logana z USA. Ten byl odsouzen za vraždu, kterou nespáchal. V souvislosti s jinou kauzou se dva advokáti dozvěděli, že skutečným vrahem je jejich klient. Protože však byli vázáni mlčenlivostí, rozhodli se ponechat si tuto informaci pro sebe. Neporušili tím žádnou právní normu platnou v USA. Pravděpodobně byli i přesvědčeni, že postupují v souladu s morálními závazky, které vyplývají z jejich profesní role. Přesto asi bude to, že ponechali nevinného člověka ve vězení, v rozporu s tím, co by většina lidí označila za morálně správné. $K$ tomuto případu viz např. WENDEL, Bradley W. Ethics and Law. An Introduction. Cambridge: Cambridge University Press, 2014, s. 3 a násl.; WENDEL, Bradley W. The Limits of Positivist Legal Ethics: A Brief History, a Critique, and a Return to Foundation. Canadian Journal of Law \& Jurisprudence, 2017, roč. 30, č. 2, s. 453-454; V českém prostředí jej ve svém článku pěkně rekapituluje Adam Benkovič. BENKOVIČ, Adam. Nemorální etika? Advokátní mlčenlivost u mylných odsouzení a srovnání úpravy v USA a ČR. Právní prostor, ATLAS consulting, spol. s r. o., 2016. Dostupné z: https://www.pravniprostor.cz/clanky/trestni-pravo/ nemoralni-etika-advokatni-mlcenlivost-u-mylnych-odsouzeni-a-srovnani-upravy-v-usa-a-cr 
kárné odpovědnosti? 'Tyto problémy jsou stručně řešeny v první části článku. Ve druhé je důkladněji objasněno, v čem spočívá problém ospravedlnění uvedených norem a proč je tak důležitý. Následující dvě části jsou věnovány analýze samotných justifikačních teorií. Nejprve je tak věnován prostor př́stupům, které můžeme podřadit pod hlavičku deontologické etiky. Mezi ně lze zařadit např́iklad známé teorie Charlese Frieda, který přirovnává advokáta k právnímu př́teli, nebo Davida Lubana, podle něhož je ústřední hodnotou, kterou právníci chrání a jež ospravedlňuje jejich činnost, lidská důstojnost. Volba těchto autorů přitom není náhodná, protože na tomto poli předkládají dvě nejucelenější teorie, které jsou i v současné zahraniční literatuře nejvíce diskutovány. ${ }^{3}$ Obě však mají určité nedostatky. V článku je tudíž předestřena a argumentována teze, že mají-li být úspěšné, musí za primární hodnotu v souladu se základními deontologickými přístupy považovat naše morální a racionální aktérství. V poslední části je nakonec ukázáno, jak lze pravidla profesní etiky advokátů ospravedlnit utilitaristicky. Navzdory tomu, že se tento směr těší u akademiků věnujících se profesní etice spíše nedůvěře, celý text uzavírá obhajoba teze, že právě na něj odkazující justifikace při zohlednění některých pragmatických požadavků a omezení může být $\mathrm{v}$ tomto rámci přinejmenším stejně věrohodná jako konkurenční deontologické teorie. V zásadě nic nebrání akceptovat obě skupiny prústupů za předpokladu, že v drtivé většině př́padů nás dovedou k totožným výsledkům.

\section{Co je profesní etika advokátů?}

Hovoří-li se o profesní etice advokátů, ne vždy bývá adekvátně objasněno, co přesně se tím má na mysli. Jedná se o soubor právních, nebo morálních norem? A pokud dává dobrý smysl charakterizovat etiku advokátní profese oběma z nich, $v$ jakém jsou tyto normy vzájemném vztahu?

Jedním ze způsobů, jak můžeme normy profesní etiky advokátů chápat, je ztotožňovat je s právní úpravou jejich kárné odpovědnosti. ${ }^{4}$ Pokud se advokát jako ustanovený obhájce nedostaví k hlavnímu líčení, přičemž obhajobu nezajistí ani substitučně, některý z kárných senátů kárné komise ČAK takové jednání vyhodnotí jako kárné provinění, protože porušuje $\int 16$ odst. 1 a 2 a $\int 17$ zákona o advokacii ve spojení s čl. 4 odst. 1

3 Srovnej např. WENDEL, 2014, op. cit., s. 32-42.

$4 \mathrm{~K}$ tomu srovnej PARKER, Christine a Adrian EVANS. Inside Lanyers' Ethics. Cambridge: Cambridge University Press, 2007, s. 4; WENDEL, Bradley W. Professional Responsibility. New York: Wolters Kluwer, 2016, s. 32; V českém prostředí tak pro účely jednoho ze svých textů činí Tomáš Friedel. Zároveň však ihned upozorňuje na limity takového př́stupu. FRIEDEL, Tomáš. Jak čeští soudci (ne)smí jednat. Praxe kárného soudu ve věcech kárných řízení se soudci v letech 2008-2014. Jurisprudence, 2015, roč. 20, č. 1, s. 15-16; Velmi kritický je k ztotožňování profesní etiky právníku s určitou právní úpravou Jan Kober. Viz KOBER, Jan. Etika soudních exekutorů. In: SOBEK, Tomáš a kol. Právní etika. Praha: Leges, 2019, s. 272; Dále srovnej i KOBER, Jan. Práunická etika jako soućást univerzitního kurikula i školení k výkonu advokátníprofese. Praha: Pro bono aliance, 2016, s. 9-10. 
a čl. 17 odst. 1 a 3 Pravidel profesionální etiky. ${ }^{5}$ Následně advokátovi za něj udělí kárné opatření, jakým je např́iklad pokuta. Takto uchopená profesní etika však není ve své podstatě opravdovou etikou ${ }^{6}$ - jedná se zde pouze o uplatňování platného práva, které reguluje, jak se mají příslušníci této právní profese v určitých situacích chovat. Dokonce zde můžeme hovořit o pozitivním právu prrímo v jeho nejtypičtějším smyslu - tedy jako o institucionalizovaných normách garantovaných státem, jejichž porušení je spojeno s určitou sankcí. Tuto sankci pak nemusí nutně udělovat státní orgán (jako třeba Nejvyšší správní soud $\mathrm{v}$ případě kárných provinění soudců a státních zástupců), ale může o ní rozhodovat i profesní samospráva (jako právě u advokátů), které je rozhodování o ní svěřeno zákonem.

Profesně-etické normy bychom ovšem nemuseli nutně chápat jen jako právní normy, ale mohli bychom je pojímat i jako součást morálky. ${ }^{7} \mathrm{~V}$ takovém kontextu dává dobrý smysl rozlišit morálku pozitivní a kritickou. ${ }^{8}$ První z nich je akceptovaná a sdílená určitou společenskou skupinou. Jedná se tudíž o institucionalizované morální normy uplatňované at' už celou společností, nebo nějakou její dílčí (třeba právě profesnî) skupinou. Druhá představuje soubor obecných principů, jejichž relevance není dána jejich praktikováním lidmi, ale morálním zdůvodňováním. Do jejího rámce pak můžeme zařadit i požadavky různých promyšlených etických teorií (např. utilitarismus nebo Kantovu etiku). Pravidla profesní etiky bychom mohli charakterizovat jako součást pozitivní morálky advokátů tedy jako morální normy, které považují advokáti za zavazující, a v praxi se jimi snaží při výkonu svého povolání řídit.

Je pochopitelné, že tyto právní i morální normy se mohou vzájemně překrývat. ${ }^{9}$ Povinnost dostavit se k hlavnímu líčení, nebo si zajistit substituci, může být zároveň stanovená právem i pozitivní morálkou. Zajímavou otázkou je, jak velká oblast bude výlučně regulována morálními normami - tedy aniž by do ní zasahovaly orgány státu nebo profesní samosprávy prostřednictvím systému kárné odpovědnosti. Lze předpokládat, že přinejmenším v České republice bude její rozsah poměrně malý, a to nejen v př́padě advokátů, ale i u ostatních právních profesí. Naše právní úprava totiž v př́padě většiny z nich obsahuje poměrně široké a velmi obecné formulace kárných provinění. Např́klad zákon o soudech a soudcích v \87 odst. 1 vymezuje kárné provinění soudce jako ,zavinèné

5 Kárné rozhodnutí kárného senátu kárné komise ČAK ze dne 31. 10. 2014, sp. zn. K 30/2014. In: SYKA, Jan (ed.). Sbirka kárných rozhodnuti Ceské advokátni komory 2014-2015. Praha: Česká advokátní komora, 2016, s. 70 a násl.

6 Právě z tohoto důvodu se někteří autoři staví velmi kriticky k označování takových právních pravidel za etiku. Viz WENDEL, 2016, op. cit., s. 33.

7 K tomu srovnej Ibid., s. 32.

8 Aplikuji zde tedy známé rozlišení na pozitivní a kritickou morálku, které ve svém díle zpopularizoval H. L. A. Hart. Viz HART, H. L. A. Law, Liberty, and Morality. Oxford, New York: Oxford University Press, 1982, s. 20.

9 WENDEL, 2014, op. cit., s. 18. 
porušeni povinností soudce, jakoož i zavinèné chováni nebo jednání, jimž̌ soudce narušuje duistojnost soudcovské funkece nebo obrožuje divèru v nezávislé, nestranné, odborné a spravedlivé rozhodování soudů. "10 V žádném jiném právním předpise už není toto provinění dále podrobněji specifikováno. V př́padě samotných advokátů obsahují sice takové specifikace Pravidla profesionální etiky a pravidla soutěže advokátů České republiky, avšak i ony v sobě zahrnují velmi široce formulovaná ustanovení, jakým je např́iklad již první odstavec jejich čtvrtého článku. ${ }^{11}$ Díky tomu může být většina prohřešků právníků řešena na právní bázi. Výjimku budou představovat spíše málo významné situace, ${ }^{12}$ př́padně situace, jejichž regulace by právní cestou nebyla efektivní. Takové budou s největší pravděpodobností řešeny výlučně na půdě morálky.

Vedle právních norem a norem pozitivní morálky ${ }^{13}$ však stojí ještě výše zmíněná kritická morálka. Oba uvedené systémy pravidel i řešení konkrétních př́padů, které nám poskytují, můžeme vždy posuzovat i z jejích pozic, ${ }^{14}$ a dokonce je z nich odmítnout jako morálně nesprávné (třeba z toho důvodu, že jsou v rozporu s principem užitku nebo Kantovým kategorickým imperativem). Takto lze hodnotit i samotná pravidla profesní etiky a situace, které regulují. Také ona mohou být prostřednictvím justifikovaných morálních principů kritizována.

Vyvstává tedy před námi důležitý rozdîl: v životě běžně narážíme na řadu problémů, u nichž se neshodneme na tom, co je v nich morálně správné a co špatné. Dokonce i tehdy, když o nich začneme uvažovat v kontextu sofistikovaných etických teorií, tak zjistíme, že zde stále zůstávají protichůdná řešení, pro něž svědčí soubor ve všech ohledech promyšlených, rozumných a korektních argumentů. Máme např́iklad přehodit výhybku, abychom změnili dráhu tramvaje a tím zachránili životy pěti lidí, které by jinak srazila, za cenu, že takto o něj prupraví jen jednoho člověka, jenž se jí touto změnou trasy

10 \ 87 odst. 1 zákona č. 6/2002 Sb., o soudech a soudcích. In: ASPI [právní informační systém]. Wolters Kluwer ČR [cit. 13. 6. 2019].

11 „Advokát je v̌seobecně povinen poctivým, čestným a slušným chováním př̈spivat ke dìstojnosti a vážnosti advokátního stavu. "Čl. 4 odst. 1 Usnesení Představenstva České advokátní komory č. 1/1997 Věstníku, Pravidla profesionální etiky a pravidla soutěže advokátů České republiky. In: Stavovskép predpisy. Ceské advokátní komora [online]. Česká advokátní komora [cit. 13. 6. 2019].

12 Ačkoliv právě u marginálních situací se nabízí otázka, zda vůbec představují nějaký morální problém. Někteři autoři jako např. H. L. A. Hart tvrdí, že pravidlo nemůžeme chápat jako součást morálky, pokud ztratilo svou důležitost. K tomu srovnej HART, H. L. A. The Concept of Law. 2. vyd. Oxford: Clarendon Press, 1994, s. 173-175. Na člověka, který bez zaklepání vtrhne do naší kanceláře, se jistě budeme zlobit, ale jen sotva mu budeme vytýkat, že tím jedná nemorálně.

13 Mám za to, že v tomto smyslu chápe pravidla profesní etiky i Martin Kopa, který ovšem ve svém jinak velmi podnětném textu tuto otázkou v zásadě netematizuje. Srovnej KOPA, Martin. Profesní etika v české právní praxi a právním vzdělávání aneb měla by profesní etika být povinnou součástí právnických studií? Casopis pro právni védu a praxi, 2013, roč. 21, č. 1, s. 22-23.

$14 \mathrm{~K}$ tomu srovnej i SHAFER-LANDAU, Russ. The Fundamentals of Ethics. 2. vyd. New York, Oxford: Oxford University Press, 2012, s. 6. 
dostane pod kola? ${ }^{15}$ Je správné mučit teroristu, aby nám prozradil, kde ukryl bombu, která může brzy vybuchnout a zabít tisíce lidí? Měli bychom dekriminalizovat a legalizovat eutanázii? To všechno jsou př́klady otázek, které vyvolávají rozepře a odbýt je mávnutím ruky s tím, že jedna strana v nich má zkrátka pravdu a druhá se přece očividně mýlí, zavání dogmatismem a ignorancí. Připouštíme tedy, že výsledkem našich úvah v oblasti kritické morálky může být i neshoda na tom, co je, nebo není morálně správné. Důvody podporující různá řešení mohou být velmi vyvážené. To však neplatí pro profesní etiku advokátů. Jejím výsledkem totiž má být - jakožto souboru pozitivních normativních pravidel - řešení konkrétního případu. Právě od toho totiž pravidla tohoto typu máme. Samozřjejmě, že dospět k němu může být v praxi velmi složité. Normy, jak už to bývá, mohou být nejednoznačné a otvírat dveře různým druhům jejích výkladu. Ze své povahy však nepřipouští, aby jejich výsledkem bylo dilema jako v prvním př́ipadě. Od profesní etiky advokátů tak musíme odlišit morální usuzování. Advokát, který v praxi čelí morálně citlivé situaci, se může vždy zeptat: „Jak bych se měl zachovat v souladu s právními normami a morálními normami, které jsou uznávány mojí profesní skupinou? " Může si však položit i odlišnou otázku: „Pro jaké jednání svědčí v této situaci nejlepší morální důvody?“ $\mathrm{Na}$ jedné straně tedy stojí institucionalizované normy, na druhé straně jejich morální kritika, která vyžaduje jejich zdůvodnění. ${ }^{16}$

\section{Justifikace profesní etiky advokátů}

V prŕpadě profesní etiky advokátů může nastat problém, pokud se její požadavky dostanou do konfliktu s postoji, které považuje za správné většina společnosti. Jinými slovy pokud se objeví napětí mezi tím, co je po člověku požadováno jakožto po advokátovi (z titulu jeho profesní role), a tím, co se zdá být v dané situaci obecně správné. ${ }^{17}$ Lze přitom souhlasit s W. B. Wendelem, že profesně-etická pravidla musí být jako celek obhajitelná i z hlediska morálních postojů společnosti, protože ta by jinak neměla důvod tolerovat existenci takové profese. ${ }^{18}$

15 Jedná se o jednu z variací známého tramvajového dilematu. Viz THOMSON, Judith Jarvis. The Trolley Problem. Yale Law Journal, 1985, roč. 94, č. 6, s. 1397. Tento zdánlivě akademický myšlenkový experiment získává v současné době hmatatelný rozměr v oblasti autonomních vozidel. K tomu srovnej KOPECKÝ, Robin. Morální problémy autonomních vozidel. Filosofický časopis, 2019, roč. 67, č. 2, s. 267-268.

16 Problematika vztahu práva a morálky je samožrejmě složitá a již v obecné rovině je řešena více odlišnými zpơsoby. Proto i ve vazbě na normy profesní etiky by mohla být pojata různě. Autor zde předkládá pouze jeden z nich, který se mu jeví pro potřeby tohoto textu jako nejvhodnější. O filosofických problémech spojených se samotným vztahem obou zmíněných normativních systémů pak v českém prostředí v mnoha svých textech velmi dobře pojednává Tomáš Sobek. Viz např. SOBEK, Tomáš. Nemorálníprávo. Praha: Akademie věd České republiky, Ústav státu a práva, 2010, 423 s.; SOBEK, Tomáš. Právni myšlení: kritika moralismu. Praha: Ústav státu a práva AV ČR ve spolupráci s Vydavatelstvím a nakladatelstvím Aleš Čeněk, Plzeň, 2011, 620 s.

17 WENDEL, 2014, op. cit., s. 5; WENDEL, 2017, op. cit., s. 445.

18 WENDEL, 2014, op. cit., s. 10. 
V tomto bodě ovšem musíme rozlišit dvě odlišné roviny tohoto problému: Nejprve si můžeme klást otázku, jak máme nejlépe zahladit rozpor mezi požadavky profesní etiky a morálními postoji většiny společnosti - tedy mezi právem a pozitivní morálkou advokátů na jedné straně a pozitivní morálkou největšího počtu lidí na straně druhé. Jako nejúspěšnějším nástrojem se tu přitom ani nemusí ukázat logicky korektní argumentace, ale např́iklad vyprávění prúběhů. ${ }^{19} \mathrm{~V}$ této rovině si přitom nemůžeme být nikdy úplně jisti, zda je správné onen rozpor opravdu pouze zahlazovat, nebo snažit se změnit postoje veřejnosti, či dokonce upravit samotné požadavky profesní etiky. Zdá se tedy, že se při takto položené otázce vytrácí z našich úvah něco podstatného. I pokud chceme jen přesvědčovat ve směru nějakého postoje, měli bychom mít pro něj nejprve dobré důvody. To nás přivádí k druhé, odlišné otázce, zda můžeme požadavky profesní etiky ospravedlnit za pomoci nějaké věrohodné etické teorie, tedy zda obstojí v procesu morálního zdůvodňování. Jestliže vưči advokátské etice směřujeme výtky typu, že nevede $\mathrm{k}$ co největšímu štěstí co největšího počtu, nebo že umožňuje advokátům způsobovat určitou újmu protistraně ${ }^{20}$ pohybujeme se právě v této rovině. Řešit takový problém je podle mého soudu právě tím zásadním. Budovat dobrý obraz právnické profese v očích společnosti je totiž chvályhodným úsilím jen tehdy, pokud takový obraz zrcadlí její skutečnou tvár. Právní normy, kterými se máme řídit, i pozitivní morálka by měly být zároveň dobře zdůvodněné. Jinak si nezaslouží, abychom je brali vážně. I proto je hlavní ambicí tohoto textu zkoumání tohoto druhého problému, a nikoliv prvního uvedeného.

Ospravedlnění profesní etiky advokátů má zpravidla instrumentální charakter v tom smyslu, že její normy pouze slouží coby nástroje k naplňování obecnějších cílů. V tomto duchu musíme chápat i Wendelovo tvrzení, že „Morálni závazky právníkư jsou odvoditelné z. funkece práva".21 Tou je podle zmíněného autora zabezpečování společenských dober, jakými jsou solidarita, pokojné soužití a plánované koordinované jednání. Úlohou právní profese je napomáhat právnímu systému v plnění těchto funkcí, což obnáší i poskytování př́istupu k oprávněním, která právo přisuzuje občanům. ${ }^{22}$ Právě tím, že advokáti zajišt'ují jednotlivcům společenská dobra založená pozitivním právem, ${ }^{23}$ přispívají k naplňování morálního cíle práva. ${ }^{24}$ Díváme-li se na celý problém takto, pak postačí, když justifikujeme tento cíl a ukážeme, že normy profesní etiky advokátů opravdu vedou k jeho naplňování.

$19 \mathrm{~K}$ této problematice srovnej některé úvahy v textu HAPLA, Martin. Když se příběhy berou vážně Richard Rorty, dialog mezi kulturami a lidská práva. Iurium Scriptum, 2018, roč. 2, č. 1, s. 17-18.

20 Srovnej FRIED, 1976, op. cit., s. 1062.

21 WENDEL, 2017, op. cit., s. 449.

22 Ibid.

23 Srovnej Ibid., s. 443.

24 Srovnej Ibid., s. 451. 
Samotné normy, které stanovují, jak se mají advokáti chovat, upravují jejich povinnosti vůči různým skupinám osob. Jedná se o jejich klienty, ostatní příslušníky jejich profese, jiné právníky, jimiž jsou zejména soudci a státní zástupci, a nakonec i o širší veřejnost. Smyslem advokátní profese však je, jak již bylo naznačeno výše, zastupování klientů, at' už před soudy a správními úřady, nebo $\mathrm{v}$ rámci různých jednání o právních otázkách s jinými fyzickými a právnickými osobami. Proto normy chování advokáta (včetně těch, které bezprostředně neupravují jeho vztah ke klientovi) musíme posuzovat tímto prizmatem. Jestliže má např́klad advokát určitým zpơsobem vystupovat na veřejnosti, spočívá důvod, který tento způsob ospravedlňuje, v tom, aby mohl v dlouhodobé perspektivě co nejlépe plnit svůj hlavní úkol, a to zastupovat různé osoby. Jeho vztah k nim je tedy primární a justifikace uvedených norem se musí v první řadě soustředit zejména na něj.

Při ospravedlňování profesní etiky advokátů bývá zpravidla odkazováno na významné morální hodnoty, jakými jsou důstojnost, autonomie, důvěra nebo pravda, které jsou realizovány prostřednictvím systému práva a činnosti právních profesí. ${ }^{25}$ Můžeme je nakonec vnímat jako ty poslední cíle, ke kterým má veškerá naše činnost (včetně působení práva) směřovat. Není překvapením, že i v tomto rámci se ukazují jako nejsilnější dvě nejvýznamnější a v současné době dominantní skupiny etických teorií - deontologická etika, k níž se dnes hlásí nejvýznamnější badatelé věnující se problematice profesní etiky, a konsekvencionalismus, který je reprezentován především utilitarismem. V následujícím textu bude věnována pozornost oběma zmíněným př́stupům.

\section{Deontologické ospravedlnění profesní etiky advokátů}

Ačkoliv je deontologická etika nejčastěji spojována se jménem významného německého filosofa Immanuela Kanta, tak v sobě ve skutečnosti zahrnuje celou řadu poměrně různorodých prrístupů a teorií. Rozdíly mezi nimi jsou někdy tak velké a zásadní, že pro ně lze jen obtížně najít jeden společný jmenovatel a pojednat o nich v obecné rovině jako o uceleném směru. I proto zpravidla bývá tento proud často negativně vymezován vůči utilitarismu, který je na rozdíl od něj velmi kompaktní. Jestliže je pro utilitarismus typické spojování správnosti jednání s jeho následky, různé př́istupy deontologické etiky právě toto spojení odmítají. Zjednodušeně řečeno, něco bychom podle nich měli dělat, nebo naopak neměli dělat, protože je to dobré, nebo špatné samo o sobě. Zabít nevinného člověka není nikdy správné a vůbec přitom nezáleží na tom, k jakým důsledkům takový čin nakonec vede. Tento důraz na určité principy, zákazy nebo práva předpokládá, že jim jsme schopni porozumět a řídit se jimi. Není proto překvapivé, že deontologické př́stupy rovněž zpravidla zdůrazňují náš status morálních a racionálních aktérů, kterému přisuzují zásadní význam. Za deontologické můžeme označit i dvě teorie, které usilujî

25 WENDEL, 2014, op. cit., s. 27. 
o ospravedlnění profesní etiky advokátů, a jimž bude v následujících řádcích věnována velká pozornost. Jsou spojeny se jmény Charlese Frieda a Davida Lubana. ${ }^{26}$ Důvody jejich výběru spočívají v tom, že jako jedny z mála př́istupů usilujících o justifikaci profesní etiky advokátů byly uceleně zpracovány, pročež představují v současném západním prostředí dva nejčastěji diskutované prrístupy.

\subsection{Teorie Charlese Frieda: advokát jako prŕítel}

Autorem první teorie, kterou zde budeme analyzovat je významný americký právník Charles Fried. Východiskem jeho koncepce je to, že obvykle považujeme za morálně správné v určitých situacích zvýhodňovat lidi, kteří jsou nám blízcí (např. naše př́ibuzné nebo přátele). ${ }^{27}$ To jej inspiruje $\mathrm{k}$ hledání analogie mezi těmito vztahy a vztahem advokáta ke klientovi. ${ }^{28}$ I ten je totiž osobní, stejně jako je poskytování právní pomoci osobní službou. ${ }^{29}$ Nakonec se tento autor přiklání k prưirovnání advokáta k prríteli, protože advokát „stejnè jako prìtel jedná v našem zájmu, a nikoliv ve svém: nebo spišse prĭjimá náš zájem za svi̊j vlastní. "30 Toto přátelství je však omezeno svým účelem - advokát je tedy někým jako našim právním př́itelem.

Fried ovšem připouští, že tato analogie je omezená hned v několika směrech - původ vztahu mezi advokátem a klientem je totiž na rozdíl od přátelství instrumentální, navíc tento vztah samotný postrádá reciproční charakter. ${ }^{31}$ Jestliže jde advokátovi o zájmy svého klienta, naopak to již neplatí. Kromě těchto anticipovaných výtek ale mohou být nadneseny i mnohé další. K rozebírané analogii je velmi kritický např́iklad W. B. Wendel. Podle něj je př́liš mnoho významných rozdílů mezi práátelstvím v jeho běžném smyslu a vztahem mezi advokátem a jeho klientem. Tím zásadním je, že druzí uvedení postrádají společnou historii, na jejímž základě by se vnímali jako lidé s navzájem sdílenými zájmy. ${ }^{32}$ Jejich vztah má nezastřeně obchodní charakter a v mnoha př́padech je ve skutečnosti velmi neosobní - jeden člověk $\mathrm{v}$ něm platí druhému, aby mu radil s komplikovanými problémy. ${ }^{33}$ Jeho zásadní charakteristiky jsou tudíž pro klasické přátelství nejen krajně netypické, ale lze dokonce říct, že jsou s ním prrímo neslučitelné. Pokud mi někdo pomáhá z toho titulu, že je mým př́telem, pak jen sotva bude chtít za svou pomoc finanční odměnu.

Fried sice explicitně odmítá, že rozebíraný vztah je běžnou ekonomickou transakcí, ale jeho argumentace se mi v tomto bodě nezdá dostatečná. Uvádí příklad, že zatímco

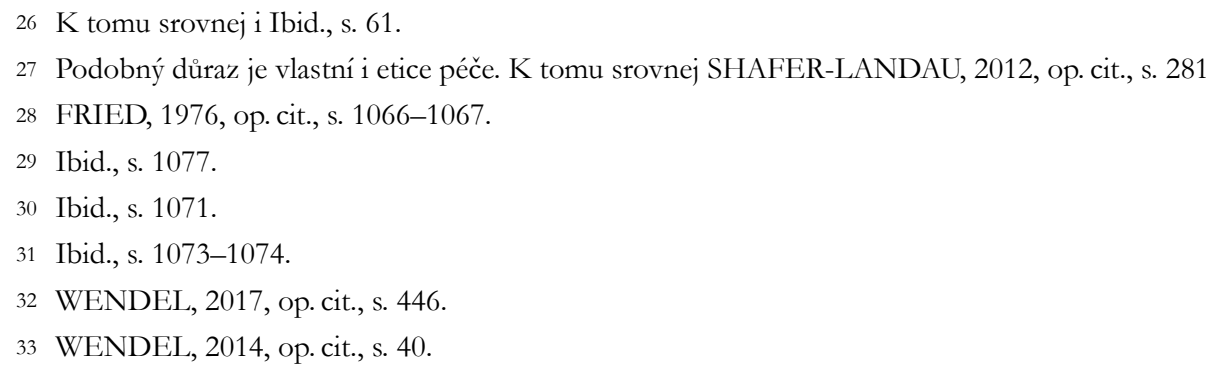


zelinář nám může odmítnout prodat zeleninu, pokud mu nezaplatíme, v případě lékaře, nebo advokáta to neplatí. Lékař nám nemůže odmítnout poskytnout zdravotní pomoc a advokát pomoc právní. ${ }^{34}$ Něco takového však platí jen v určitých situacích. To, že výkon advokacie $\mathrm{v}$ nich opravdu přesahuje běžné poskytování služeb za úplatu, nevylučuje, že po většinu času právě takový charakter má. Jedná se zde tedy o netypické případy a je proto otázkou, proč by na jejich základě měl být poskytován advokátovi nějaký zvláštní status i v těch typických. Skutečnost, že tento vztah má ve srovnání s jinými ekonomickými transakcemi určitá omezení, pro která ostatně existuje řada dobrých důvodů (např. poukazem na princip odvracení závažné újmy můžeme snadno ospravedlnit, že lékař musí ošetřit těžce raněného pacienta bez zdravotního pojištěnî), ještě samo o sobě neposkytuje relevanci analogii vedené směrem $\mathrm{k}$ přátelství. To, že nám advokát někdy musí poskytnout bezplatnou právní pomoc, sice není v kontextu obchodních transakcí běžné, ale ještě to z něj nedělá našeho přítele a jeho vztahu vưči nám nutně nedodává charakter, s nímž je spojený nějaký zvláštní a význačný morální status.

Bylo by ovšem chybou se v prŕpadě Friedovy teorie soustředit pouze na specifické rysy, které má mít vztah mezi advokátem a jeho klientem. Tím bychom opomíjeli jeden důležitý aspekt jeho prŕstupu, kterým je jeho zaměření na autonomii. Fried ve svém textu opakovaně zdůrazňuje, že advokátovi jde o to do určité míry udržovat a vyjadřovat autonomii svého klienta ve vztahu k právnímu systému. ${ }^{35}$ Pokud budeme toto vnímat jako centrální myšlenku jeho př́stupu, ztratí většina výše nastíněných výtek na závažnosti. Klíčový zde totiž už nebude interpersonální vztah mezi advokátem a klientem, ale hodnota autonomie člověka, a to, nakolik k ní advokát svou činností přispívá. Aby byla uchována i ve spletitém světě práva, je $\mathrm{v}$ př́padě právně neškolených lidí nepochybně potřeba, aby jim byl kompenzován jejich nedostatek odborných znalostí a argumentačních dovedností. $\mathrm{V}$ rámci takové kompenzace by pak mělo být pro advokáta $\mathrm{v}$ zásadě přípustné všechno, co by v souladu se zákonem mohl učinit i jeho klient, pokud by disponoval př́slušnými znalostmi. Takový závěr však už můžeme považovat spíše za jednu z rozšiřujících interpretací analyzované teorie. Za správné lze ovšem považovat konstatování, že samotný interpersonální charakter vztahu mezi advokátem a jeho klientem není schopen poskytnout uspokojivý základ pro ospravedlnění souvisejících norem profesní etiky.

\subsection{Teorie Davida Lubana: důstojnost jako klíčová hodnota}

Podle amerického právního filosofa Davida Lubana činí praktikování práva hodnotným to, že podporuje lidskou důstojnost. ${ }^{36}$ Právě ta představuje v jeho pojetí klíčovou hodnotu, jejímž prostřednictvím je profesní etika advokátů ospravedlněna.

\footnotetext{
34 FRIED, 1976, op. cit., s. 1075.

35 Srovnej Ibid., s. 1073-1075, 1077.

36 LUBAN, David. Legal Ethics and Human Dignity. Cambridge: Cambridge University Press, 2007, s. 66.
} 
Důstojnost samotná samozřejmě představuje obtížně uchopitelný pojem, který může být koncipován mnoha, často velmi odlišnými, způsoby. ${ }^{37}$ Lze např́iklad rozlišit její různá pojetí, která ji prrisuzují aspirující, nebo nedotknutelný charakter. ${ }^{38} \mathrm{I}$ proto vyžaduje rozebíraný prrístup určité upřesnění: Důstojnost je v něm dávána do souvislosti s tím, že člověk stojící před soudem může vyprávět svůj príběh a být vyslechnut. ${ }^{39}$ Advokát představuje jeho hlas, který tento př́běh vypráví a interpretuje právo z jeho hlediska. Luban tedy důstojnost spojuje se subjektivitou ${ }^{40}$ a její popření považuje za ponížení člověka. ${ }^{41}$ Chápe ji jako určité postavení. ${ }^{42}$ Jinak řečeno, pokud je s někým jednáno způsobem, který odpovídá postavení nižšímu, je s ním zacházeno nedůstojně a takový člověk je ponižován. ${ }^{43}$ Takto pojatá důstojnost se však může lišit v závislosti na konkrétní společnosti, ve které se pohybujeme. Luban proto říká, že lidská důstojnost odkazuje k prestiži, kterou máme na základě toho, že jsme lidskými bytostmi. Jedná se tudíž o postavení, které vyžaduje, aby s námi nebylo zacházeno jako se zvířaty, nástroji, majetkem, objekty, podlidmi nebo velkými dětmi. ${ }^{44}$ Jestliže samotná důstojnost koncipovaná jako postavení může být relativní $\mathrm{k}$ různým společenstvím a kulturám, lidská důstojnost má oproti ní univerzální charakter.

Tím se již pomalu dostáváme k citlivému bodu celé teorie, kterým je otázka, jak souvisí tento koncept s autonomií. Nebylo by nakonec dobré obojí ztotožnit? ${ }^{45}$ Právě to Luban odmítá. ${ }^{46}$ Autonomie se totiž podle něj zaměřje pouze na jednu lidskou schopnost, kterou je vưle a uskutečňování svobodné volby. Tím by byla opomíjena široká oblast lidské praxe (např. vnímání, pocit’ování utrpení, reflexe...). Oceňování něčí důstojnosti tak podle něj máme pojímat jako oceňování jeho bytí, a nikoliv pouze vưle. ${ }^{47}$ Tím je opět zdůrazněna subjektivita člověka coby východisko celého prŕístupu.

37 Srovnej HAPLA, Martin. Lidská práva bez metafyziky: legitimita v (post)moderní dobè. Brno: Masarykova univerzita, 2016, s. 112 a násl.

38 Viz SCHROEDER, Doris. Human Rights and Human Dignity. Ethical Theory and Moral Practice, 2012, roč. 15 , č. 3 , s. 332 .

39 Srovnej LUBAN, 2007, op. cit., s. 68.

40 Ibid., s. 71.

41 Ibid., s. 72.

$42 \mathrm{~S}$ tím srovnej to, jak $\mathrm{k}$ důstojnosti pristupuje Jeremy Waldron, podle kterého představuje statusový a nikoliv hodnotový koncept. WALDRON, Jeremy. Is Dignity the Foundation of Human Rights? In: CRUFT, Rowan, Matthew S. LIAO a Massimo RENZO (eds.). Philosopbical Foundations of Human Rights. 1. vyd. Oxford: Oxford University Press, 2015, s. 133.

43 LUBAN, 2007, op. cit., s. 89.

44 Ibid.

45 Ibid., s. 74-75.

46 Ibid., s. 76, 84.

47 Ibid., s. 76. 
Právě tento široký základ lidské důstojnosti považuji za jeden z jeho nejvíce problematických aspektů. Je zde totiž zcela opomíjeno, že je třeba obhájit, v čem spočívá specifičnost člověka vůči zvířatům, nebo různým objektům. Zvíre stejně jako člověk vnímá, trpí, pocit'uje štěstí, i jeho bytí samotné má určitou hodnotu. Pokud mají mít lidské bytosti vưči nim nějaké speciální postavení, nějakou důstojnost, kterou jiní tvorové nemají, musí ji mít na základě něčeho, čím se od nich liší. Právě tato odlišnost bývá již tradičně viděna v lidské schopnosti být racionálním nebo morálním aktérem ${ }^{48}$ a jen obtížně může být viděna $\mathrm{v}$ něčem jiném. Důstojnost člověka tudíž musí být primárně provázána na tuto schopnost s tím, že ostatní lidské schopnosti jsou chráněny pouze coby instrumenty a nezbytné podmínky takového aktérství. ${ }^{49}$ To, že na lidech oceňujeme právě jejich schopnost provádět racionální volby a zdůvodňovat je, ale neznamená, že jejich ostatní schopnosti nemají požívat nějaké specifické ochrany - jen ji získávají na základě svého vztahu k ní.

To však není jediná výtka, kterou lze vůči Lubanově teorii nadnést. Sám její autor připouští, že advokáty a jejich klienty v řízení před soudem ve skutečnosti zajímá spíše výsledek kauzy a nikoliv to, jak věrně advokát reprodukuje prŕběh svého klienta. ${ }^{50}$ To by samo o sobě nemuselo představovat tak těžkou ránu, avšak důraz na reprodukování prŕběhu s sebou přináši i mnohé další potíže. Advokát by např́iklad neměl záměrně vyprávět př́běh, který je falešný. ${ }^{51}$ Proto Luban vnímá jako velmi citlivou otázku, zda advokát může konstruovat příběh, který ve skutečnosti nemá nic společného s jeho klientem. Jako př́klad prritom zmiňuje situaci, kdy je nějaký člověk dopaden, jak nakládá na zadní sedadlo svého auta ukradený televizor a je následně obviněn z držení kradené věci. Hajî se přitom tím, že jej koupil od další osoby a o jeho skutečném původu nic nevěděl. Jeho advokát na jeho obhajobu uvádí argument, že pokud by jeho klient věděl, že věc je kradená, neukládal by ji na viditelné sedadlo, ale uložil by ji do zavazadlového prostoru, kde by nebyla tolik na očích. Zamlčí přitom, že klient ji dával tam, kam ji dával, z toho důvodu, že od zavazadlového prostoru zrovna neměl klíče. ${ }^{52}$ Podle Lubana je i takový postup advokáta přijatelný. U soudu lze předkládat argumenty, které jsou konzistentní s důkazy dokonce i tehdy, pokud nemají nic společného s realitou. Důstojnost svého klienta může totiž advokát hájit nejen přímo tím, že vypráví jeho příběh, ale i neprúmo tím, že demonstruje, že na základě důkazů může být zkonstruován přiběh o jeho nevině. ${ }^{53}$

48 K tomu srovnej např. GRIFFIN, James. On Human Rights. 1. vyd. Oxford: Oxford University Press, 2008, s. 45.

49 Svobodu a určitý blahobyt (well-being) pojímá jako nezbytné podmínky našeho jednání a tedy i normativního aktérství Alan Gewirth. K tomu viz např. GEWIRTH, Alan. The Epistemology of Human Rights. Social Philosophy \& Policy, 1984, roč. 1, č. 2, s. 18; Srovnej i GEWIRTH, Alan. Reason and Morality. Chicago and London: The University of Chicago Press, 1981, s. 48 a násl.

50 LUBAN, 2007, op. cit., s. 69.

51 Ibid., s. 70.

52 Srovnej Ibid., s. 72.

53 Ibid., s. 73. 
Zde se ovšem nabízí námitka, zda takovým postupem nemůže zasáhnout do důstojnosti jiných osob, třeba těch, kteří byli krádeží televizoru poškozeni. Pokud by měla být právě důstojnost brána jako ona zásadní hodnota, vždy tu zůstává problém, že ochranou důstojnosti někoho, můžeme zasahovat do důstojnosti někoho jiného. Sám Luban nám neříká, jak bychom měli takový konflikt řešit. Ve výše uvedeném prrípadě se však ukazuje, že argumenty, proč může advokát postupovat, jak postupoval, nebudou souviset pouze s důstojností, ale budou zejména pragmatické. Jeho postup můžeme obhajovat např́iklad tím, že sám advokát nemůže nikdy stoprocentně vědět, jestli mu jeho klient nelže. Proto by i on (stejně jako všichni ostatnî) měl své úsudky zakládat především na důkazech a teprve $v$ jejich světle hodnotit váhu toho, co tvrdí samotný klient. Něco takového však znamená zohledňovat určité aspekty, s nimiž zkoumaná teorie (přinejmenším) explicitně přiliš nepočítá.

Další možnou námitkou, kterou lze vůči rozebrané teorii nadnést, je její úzké zaměření na situace, kdy advokát svého klienta zastupuje v soudním řízení. Ty sice stojí v centru jeho profesní činnosti, ale úplně její obsah nevyčerpávají. Samotný aspekt podpory lidské důstojnosti bychom sice mohli pravděpodobně identifikovat i v jejich dalších oblastech, ale v každém př́padě bychom pak museli predefinovat řadu prvků Lubanova př́stupu (např. samotné vymezování důstojnosti skrze možnost vyprávět svůj př́běh před soudem a být vyslechnut). Ve srovnání s Friedovým je tudíž jeho nespornou nevýhodou i užší rámec jeho možné aplikace.

\subsection{Důraz na morální a racionální aktérství jako základní kámen profesní etiky advokátů}

Pokud chceme úspěšně ospravedlnit profesní etiku advokátů na deontologické bázi, je třeba podle mého soudu soustředit svou pozornost nikoliv na specifickou povahu vztahu mezi advokátem a jeho klientem, ale na význam, kterou má činnost advokáta pro uchování morálního aktérství jeho klienta. To, že je někdo morální aktér, znamená, že je schopen kontrolovat své jednání skrze zvažování jeho důvodů. ${ }^{54}$ Jestliže jsou podle Wendela zakládajícími hodnotami profesní etiky právníků důstojnost a aktérství občanů ${ }^{55}$ lze s ním proto souhlasit jen z poloviny, protože koncept lidské důstojnosti může být jen stěží obhájen bez odkazu k druhému uvedenému. ${ }^{56}$ Důraz na naše aktérství přitom umožňuje zohledňovat i řadu dalších hodnot, které však musí být pojímány jako instrumentální. Abychom mohli být aktéry, musí být totiž naplněny určité podmínky. Například musíme mít zajištěn základní životní standard, který umožňuje naše přežití

54 SHAFER-LANDAU, 2012, op. cit., s. 75.

55 WENDEL, 2017, op. cit., s. 463.

56 Resp. takový koncept lidské důstojnosti by byl obhajitelný jen na náboženské bázi, což je však irelevantní obhajoba pro lidi, kteří nejsou věŕící. K tomu srovnej některé úvahy v publikaci HAPLA, 2016, op. cit., s. $100,116-117$. 
a rozvoj našich rozumových schopností. Proto dává dobrý smysl klást důraz i na dosažení takových podmínek. Jejich význam však netkví v nich samotných, ale získávajî ho teprve jakožto prostředky, které nám umožňují být aktéry.

Stojí za povšimnutí, že deontologické zdůvodnění můžeme koncipovat i jako neinstrumentální - tedy normy profesní etiky právníků jsou tu od toho, aby př́mo přispívaly k uchování aktérství advokátova klienta. $\mathrm{V}$ takovém případě samožrejmě můžeme čelit možným konfliktům mezi požadavky, které vyplývají z ochrany jeho aktérství, s požadavky na ochranu aktérství jiných osob (podobně jako v případě důstojnosti u Lubana). Lze je podle mého soudu řešit za pomoci proporcionality. ${ }^{57}$ Mnohem lepší smysl však podle mého soudu dává zasadit uvedené zdůvodnění do onoho širšího rámce a zdůraznit, že aktérství jednotlivce má být chráněno právem jako celkem s tím, že profesní etika právníků príspívá $\mathrm{k}$ tomu, že právo je schopno tento úkol uspokojivě plnit. Tím se výše popsané napětí mezi požadavky na ochranu aktérství různých osob eliminuje, nebot' právě důraz na fungování práva jako celku nám poskytuje hledisko, ze kterého můžeme naznačené konflikty řešit.

\section{Utilitaristické ospravedlnění profesní etiky advokátů}

Ačkoliv se v našich odborných kruzích někdy dostává utilitarismu spíše rezervovaného přijetí, jedná se o jednu z nejpromyšlenějších, nejvíce diskutovaných a nejvlivnějších etických teorií. Je spojován zejména s osobou svého zakladatele Jeremy Benthama a jeho významného žáka Johna Stuarta Milla, který věnoval velkou pozornost, jak propojit tuto teorii s koncepty lidských práv a svobody jednotlivce. Sám Mill základní princip utilitarismu charakterizuje tak, že jednání je správné úměrně tomu, nakolik podporuje štěstí, a nesprávné, nakolik vede k jeho úbytku. ${ }^{58}$ Jeho správnost tak můžeme posoudit na základě určitého kalkulu - sečteme štěstí a neštěstí, které nám z něj plynoucí důsledky přinášejí. V rámci tohoto přístupu samozřejmě existuje řada dílčích a v některých aspektech odlišných proudư, ${ }^{59}$ o všech utilitaristech však můžeme říct, že jsou konsekvencionalisté (posuzují správnost jednání výlučně na základě jeho následků), je pro ně důležitá maximalizace užitku (ten může být chápán různým způsobem - třeba jako potěšení, nebo splněná preference) a přistupují ke všem nestranně (štěstí nebo splněným preferencím každého subjektu je přikládána stejná váha).

Utilitarismus tedy ve srovnání s deontologickou etikou představuje poměrně kompaktní směr. Jeho velkou výhodou je jeho snadná a široká aplikovatelnost. Mưžeme jím

57 Princip proporcionality samozřejmě představuje rozsáhlé a členité téma. V našem prostředí o něm zatím nejuceleněji pojednává Pavel Ondřejek. Viz jeho monografie ONDŘEJEK, Pavel. Princip proporcionality a jeho role pri interpretaci základnich práv a svobod. Praha: Leges, 2012, 224 s.

58 MILL, John Stuart. Utilitarianism. Auckland: The Floating Press, 2009, s. 14.

59 Stručné a přehledné shrnutí základních zásad tohoto směru a jeho druhů viz SHAFER-LANDAU, 2012, op. cit., s. 117 a násl. 
snadno posuzovat správnost nejen našeho jednání, ale i politických a právních institucí. Představuje i jednu ze stěžejních teorií distributivní spravedlnosti. ${ }^{60}$ Navzdory jeho aplikaci na různorodé oblasti se přitom stále jedná o jednu totožnou obecnou teorii, která se zcela obejde bez jakýchkoliv specifických úprav. To platí i pro oblast profesní etiky advokátů. Zatímco $\mathrm{v}$ rámci deontologické etiky na této půdě vznikají zvláštní teorie, pro utilitarismus nic takového neplatí. ${ }^{61}$

V př́padě profesní etiky advokátů ji můžeme utilitaristicky ospravedlnit tak, že ukážeme, že dodržování jejich norem vede $\mathrm{k}$ maximalizaci užitku. Do tohoto zpo̊sobu uvažování lze prritom velmi snadno přepsat některé tradiční a obecně snadno akceptované argumenty, které mají justifikovat zvláštnosti související s profesní rolí právníků. Tím je např́íklad argument dělbou práce. ${ }^{62}$ Pokud má právo jako celek dobře fungovat, musí jednotliví právníci dobře plnit své profesní role. Jestliže by třeba advokáti mohli vyzrazovat tajemství svých klientů, jen těžko by požívali jejich důvěru. Bez této důvěry by přitom jen stěží bylo možné efektivní vedení obhajoby, což by se podepsalo na špatném fungování práva. K maximalizaci užitku tak nakonec lépe přispěje, pokud bude povinnost mlčenlivosti advokáty dodržována, než aby jimi byla porušována. Právě tím, že o ospravedlnění profesní etiky právníků obvykle uvažujeme v instrumentální rovině, je v jeho rámci utilitaristické zdůvodnění dobře aplikovatelné.

Avšak i vůči této justifikaci lze nadnést různé námitky. Činí tak např́iklad již zmíněný Charles Fried. ${ }^{63}$ Sám o sobě rríká, že nedokáže pochopit, jak může někdo zároveň považovat obecné dobro za jediný morální standard a zároveň vytrvale dodržovat své závazky vưči přátelům, rodině a klientům. ${ }^{64}$ Ospravedlnění toho, že takové závazky bereme vážně, nemůže být podle něj instrumentální jako v př́padě utilitaristického, ale musí jim přisuzovat alespoň do určité míry vnitřní hodnotu, ${ }^{65}$ což dokáže pouze nějaká forma deontologicky koncipovaného zdůvodnění.

Na uvedenou námitku můžeme reagovat poukazem na tzv. utilitarismus pravidel. ${ }^{66}$ Ten se ostatně snaží odpovědět i na jinou tradiční výtku směřovanou vůči tomuto směru, která spočívá v tom, že není realistické, abychom u každého našeho jednání prováděli

60 WELLMAN, Christopher Heath. Justice. In: SIMON, Robert L. The Blackwell Guide to Social and Political Philosophy. Malden and London: Blackwell Publishers Ltd, 2002, s. 60-64.

61 To lze např́ḱlad pěkně vidět na způsobu, jak William C. Starr justifikuje prostřednictvím utilitarismu různé etické kodexy. K tomu viz STARR, William C. Codes of Ethics - Towards a Rule-Utilitarian Justification. Journal of Business Ethics, 1983, roč. 2, č. 2, s. 99 a násl.

62 Stručný popis tohoto argumentu viz v monografii WENDEL, 2014, op. cit., s. 6.

63 Srovnej FRIED, 1976, op. cit., s. 1067.

64 Ibid., s. 1068.

65 Ibid. Výrazem vnitřní hodnota překládám anglický termín intrinsic value.

66 Velmi stručné shrnutí tohoto druhu utilitarismu viz v publikaci RACHELS, James a Stuart RACHELS. The Elements of Moral Philosophy. New York: McGraw-Hill, 2012, s. 119 a násl. 
hedonistický kalkul a počítali, kolik štěstí nebo neštěstí nám přinese. ${ }^{67}$ Proto bychom neměli kalkulovat, jaké konkrétní jednání nejvíce přispěje k maximalizaci užitku. Naopak bychom měli zjistit, jaký soubor obecných pravidel jej nejvíce zvyšuje, a tímto souborem se pak bez výjimek řídit. Jestliže bude součástí takového souboru dodržování závazků vůči prátelům, rodině a klientům, měli bychom je vytrvale dodržovat přesně $v$ tom duchu, v jakém to požaduje Fried.

I utilitarismus pravidel ovšem taktéž čelí silné kritice, a to přímo ze strany některých utilitaristů. Je jimi považován za iracionální. Proč bychom totiž měli dát přednost výsledkům utilitarismu pravidel před výsledky utilitarismu činů, které jsou s nimi v rozporu, když ty první $\mathrm{z}$ nich $\mathrm{v}$ daných případech ve skutečnosti $\mathrm{k}$ maximalizaci užitku vůbec nevedou? ${ }^{68}$ Možná odpověd' může spočívat $\mathrm{v}$ tom, že připustíme, že žádné pravidlo by nemělo být dodržováno absolutně, že každé připouští v určitých extrémních situacích výjimky. Ve standardních situacích je z hlediska utilitaristické logiky správné taková pravidla dodržovat. Samotný užitek spojený s porušením nějakého pravidla bývá totiž převážen užitkem, který máme z toho, že nemusíme provádět zvláštní kalkulaci pro každé jednání. Navíc zde musíme připočíst i užitek spojený s tím, že obecná pravidla nám poskytují i určitou jistotu stran chování ostatních a usnadňují nám tak vytváření našich životních plánů. ${ }^{69}$ To, že mohou nastat výjimečné situace, kdy bude morálně správné nějaké pravidlo porušit, pak nemusí být nutně vnímáno jako problém, ale spíše jako výhoda. Celý systém tím získává na určité flexibilitě a je tak schopný se vyvarovat některých křiklavých a absurdních důsledků, které mohou být s absolutním dodržováním některých norem spojeny. Jistěže je třeba dodržovat dané slovo, ale ne tehdy, když jeho porušením můžeme zachránit svět před zkázou. Dobré právo ostatně s takovými výjimečnými situacemi samo počítá a umožňuje je řešit například prostřednictvím různých institutů dávající státním orgánům možnost uvážení, prezidentské milosti apod. Nejvíce bude společenský užitek totiž zvyšovat takový soubor obecných pravidel, který bude požadovat, aby byla uplatňována sice důsledně, nikoliv však slepě.

\section{Závěr}

V tomto textu bylo poukázáno na to, že ospravedlnění profesní etiky právníků si musí brát jako výchozí hodnoty bud' morální aktérství člověka a na něj provázanou autonomii nebo užitek a s ním související koncept štěstí, pokud má být smysluplné. Takový závěr není překvapivý, protože právě autonomie a štěstí bývají pojímány jako dvě entity,

67 O této námitce se ostatně zmiňuje a následně na ni i reaguje již John Stuart Mill. Viz MILL, 2009, op. cit., s. 42.

68 Srovnej SHAFER-LANDAU, 2012, op. cit., s. 151.

69 S tím srovnej i některé úvahy v textu BRANDT, R. B. Utilitarianism and Moral Rights. Canadian Journal of Philosophy, 1984, roč. 14, č. 1, s. 12 a násl. 
které jsou hodnotné samy o sobě. ${ }^{70}$ Je proto pochopitelné, že téměř každá justifikace musí alespoň z jedné z těchto hodnot nějakým způsobem vycházet. Deontologické i utilitaristické ospravedlnění profesní etiky právníků má přitom své silné i slabé stránky. Proto není vhodné ze související debaty vyřadit ani jedno z nich. Do budoucna by naopak mohlo dávat dobrý smysl uvažovat o jejich propojení. To může mít samozřejmě různou podobu. Nelze vyloučit, že obě ospravedlnění mohou vést v určitých situacích k odlišným nebo konfliktním závěrům. Přesto se domnívám, že ve většině situací se budou ve svých závěrech shodovat. $V$ takovém př́padě je možno vztáhnout i na normy profesní etiky právníků Rawlsův koncept překrývajícího se konsenzu. ${ }^{71}$ Můžeme je tedy akceptovat na základě vzájemně neslučitelných zdůvodnění, protože navzdory svým odlišnostem nás v praxi vedou k totožným výsledkưm. Tím se otvírá prostor pro uplatnění obou justifikací. Ambicióznější alternativou by bylo usilovat o př́mé provázání deontologické a konsekvencionalistické etiky, což se ovšem dlouhodobě ukazuje jako poměrně obtížný úkol.

Normy profesní etiky právníků dává asi nejlepší smysl vnímat jako instrumenty, které mají umožnit, aby právo dobře fungovalo a plnilo své klíčové úkoly, které ostatně nakonec také souvisí s podporou autonomie a štěstí člověka. V liberální společnosti by právo mělo především představovat projekt, který má umožnit těžit všem lidem ze společenské kooperace navzdory jejich specifickým morálním cílům. I tento jeho charakter lze dobře odůvodnit s odkazem na obě zmíněné základní hodnoty. Je však třeba si uvědomit, že zároveň dává profesní etice určitý tvar i limity. Je např́klad důvodem, proč musí advokát při zastupování klienta odhlížet v morálně kontroverzních otázkách od svých vlastních morálních postojů. ${ }^{72}$

Problematika ospravedlnění profesní etiky právníků a jejich vazeb na etické a politické teorie má tudíž nejen velký význam, ale je i poměrně spletitá. Úkolem tohoto krátkého textu pochopitelně nemohlo být pojmout ji vyčerpávajícím zpo̊sobem, spíše naznačit její základní kontury coby odrazový můstek pro další zkoumání, které si i v našem prostředí nepochybně zaslouží.

\footnotetext{
70 SHAFER-LANDAU, 2012, op. cit., s. 35.

71 K tomuto konceptu viz RAWLS, John. Political Liberalism. Rozšířené vyd. New York: Columbia University Press, 2005, s. 133 a násl.

72 WENDEL, 2017, op. cit., s. 450.
} 